\title{
Potensi Antibakteri Ekstrak Daun Pedada (Sonneratia Caseolaris) Sebagai Pengawet Alami Ikan Kembung (Rastrelliger Sp) Segar \\ Potential Antibacterials of Pedada Leaf Extract (Sonneratia caseolaris) as A Natural Preservative in Fresh Mackerel (Rastrelliger sp)
}

\author{
Nirmala Efri Hasibuan*), Sumartini \\ Politeknik Kelautan dan Perikanan Dumai, Jl. Wan Amir No.1, Kota Dumai, Riau, Indonesia \\ *) email korespondensi: nirmala.efrihsb@gmail.com
}

\begin{abstract}
Preservation is one way to prevent the deterioration of fish quality. This study aims to utilize pedada leaf extract (Sonneratia caseolaris) as a natural preservative in fresh mackerel. This research was divided into three stages, namely sample preparation, pedada leaf extraction and extract application to fish. This study used a completely randomized factorial design consisting of three factors. The first factor was the addition of pedada leaf extract. The second factor is the storage temperature of fish, namely room temperature $\left(23^{\circ}-27^{\circ} \mathrm{C}\right)$, cold temperature $\left(10^{\circ} \mathrm{C}\right)$, freezing temperature $\left(0^{\circ} \mathrm{C}\right)$. The third factor is storage time, namely 1, 7 and 14 days. Each treatment was repeated twice. Parameters tested include $\mathrm{pH}$ value, water content, protein content, total plate number (ALT) and E-coli. The results showed that the addition of pedada leaf extract, differences in storage temperature, and storage time had a significant effect ( $\mathrm{sig}<0.05$ ) on the $\mathrm{pH}$ value, water content, protein content and total plate number (ALT). Furthermore, the results of the E-coli test showed that the treatment of cold temperature and freezing temperature on fish with the addition of pedada leaf extract showed negative E-coli content.
\end{abstract}

Keywords: Mackerel, Mangrove, Sonneratia caseolaris, E-coli, Preservation

\begin{abstract}
ABSTRAK
Pengawetan merupakan salah satu cara untuk menghambat kemunduran mutu ikan. Penelitian ini bertujuan untuk memanfaatkan ekstrak daun pedada (Sonneratia caseolaris) sebagai bahan pengawet alami pada ikan kembung segar. Penelitian ini dibagi menjadi tiga tahap yaitu persiapan sampel, ekstraksi daun pedada dan aplikasi ekstrak pada ikan. Penelitian ini menggunakan Rancangan Acak Lengkap Faktorial yang terdiri dari tiga faktor. Faktor pertama adalah penambahan ekstrak daun pedada. Faktor kedua adalah suhu penyimpanan ikan yaitu suhu ruang $\left(23^{\circ}-27^{\circ} \mathrm{C}\right)$, suhu dingin $\left(10^{\circ} \mathrm{C}\right)$, suhu beku $\left(0^{\circ} \mathrm{C}\right)$. Faktor ketiga adalah lama penyimpanan yaitu 1,7 dan 14 hari. Masingmasing perlakuan dilakukan pengulangan sebanyak dua kali. Parameter yang diuji meliputi nilai $\mathrm{pH}$, kadar air, kadar protein, angka lempeng total (ALT) dan E-coli. Hasil penelitian menunjukkan bahwa penambahan ekstrak daun pedada, perbedaan suhu penyimpanan, dan lama penyimpanan berpengaruh signifikan $($ sig $<0.05)$ terhadap nilai $\mathrm{pH}$, kadar air, kadar protein dan angka lempeng total (ALT). Selanjutnya hasil uji E-coli diperoleh bahwa perlakuan suhu dingin dan suhu beku pada ikan dengan penambahan ekstrak daun pedada menunjukkan kandungan E-coli negatif.
\end{abstract}

Kata Kunci: Ikan Kembung, Mangrove, Sonneratia caseolaris, E-coli, Pengawetan

\section{PENDAHULUAN}

Ikan kembung dalam pasar pangan global menjadi salah satu spesies ikan komersial pelagis yang paling penting. Kualitas ikan kembung dipengaruhi oleh jenis, musim, daerah penangkapan, status gizi, cara penangkapan, penanganan, dan penyimpanan (Huang et al., 2021). 
Ikan kembung memiliki sifat mudah mengalami kerusakan bila tidak ditangani dengan baik. Hal ini disebabkan pertumbuhan mikroba yang cepat yang secara alami ada pada ikan atau dari kontaminasi (Husni et al., 2015). Penurunan mutu ikan dapat dihambat melalui perlakuan tertentu seperti pendinginan dan pembekuan atau dengan pemberian bahan tambahan (Sormin et al., 2021).

Bahan yang paling umum digunakan dalam menghambat pertumbuhan bakteri adalah bahan kimia namun beberapa bahan kimia memiliki efek samping terhadap kesehatan. Oleh karena itu diperlukan bahan tambahan alami yang aman digunakan dan bisa mengawetkan bahan pangan. Pengawet alami dapat berasal dari mikroorganisme, hewan dan tumbuhan (Mei et al., 2019).

Dalam beberapa penelitian terdapat bahan pengawet alami dari tumbuhan yang mampu menghambat kemunduran mutu ikan karena mengandung senyawa bioaktif (Husni et al., 2015). Beberapa penelitian yang menggunakan bahan pengawet alami pada ikan antara lain penelitian penggunaan senyawa bioaktif yang terdapat pada buah Avicennia marina terhadap tingkat oksidasi ikan nila merah dan hasil menunjukkan bahwa senyawa bioaktif tersebut efektif dalam menghambat laju oksidasi pada ikan (Sipayung et al., 2015). Ekstrak daun api-api (A.marina) memiliki daya hambat terhadap pertumbuhan mikroba pada ikan tongkol segar (Iswadi et al., 2015) dan ikan layang segar (Sormin et al., 2021) dengan menunjukkan hasil yang berpengaruh nyata terhadap kualitas ikan tanpa mempengaruhi nilai organoleptik ikan tersebut.

$\begin{array}{lrrr}\text { Penelitian ini } & \text { bertujuan } & \text { untuk } \\ \text { memanfaatkan } & \text { ekstrak } & \text { daun pedada } \\ \text { (Sonneratia caseolaris) } & \text { sebagai } & \text { bahan }\end{array}$ pengawet alami pada ikan kembung segar dengan pengaruh perbedaan konsentrasi ekstrak, suhu/kondisi penyimpanan dan lama penyimpanan. Daun pedada (S.caseolaris) mengandung senyawa metabolit sekunder seperti alkaloid, flavonoid, fenolik dan tanin yang berperan sebagai antibakteri. Ekstrak daun S.caseolaris dapat menghambat pertumbuhan Salmonella sp (Shofiana, 2020).

\section{METODOLOGI PENELITIAN}

\begin{abstract}
Alat
Peralatan yang digunakan dalam penelitian ini adalah neraca analitis (Kern ABS-N/ABJ-NM), Blender (Philips), oven (Binder), Stomacher (Chemopure BK - 04 C), Hot plate stirrer (Heidolph), incubator (Sant Carbothermic), autoclave (Gea 121-1410), alat-alat gelas (pyrex), Vortex mixer (Barnstead Maxi Mix II), $\mathrm{pH}$ meter (Eutech $\mathrm{pH})$.
\end{abstract}

\section{Bahan}

Bahan-bahan yang digunakan dalam penelitian ini adalah daun pedada (S. caseolaris), ikan kembung (Rastrelliger sp), es batu, akuades, alkohol $96 \%$ (p.a merck), plate count agar (p.a merck), butterfield's phosphate buffered (p.a merck), lauryl trypose broth (p.a merck), EC broth (p.a merck).

\section{Prosedur Penelitian}

Penelitian ini dibagi menjadi tiga tahap yaitu persiapan sampel, ekstraksi daun pedada dan aplikasi ekstrak pada ikan. Penelitian ini menggunakan Rancangan Acak Lengkap Faktorial yang terdiri dari tiga faktor. Faktor pertama adalah penambahan ekstrak daun pedada dan kontrol tanpa penambahan ekstrak. Faktor kedua adalah suhu penyimpanan ikan yaitu suhu ruang $\left(23^{\circ}-27^{\circ} \mathrm{C}\right)$, suhu dingin $\left(10^{\circ} \mathrm{C}\right)$, suhu beku $\left(0^{\circ} \mathrm{C}\right)$. Faktor ketiga adalah lama penyimpanan yaitu 1,7 dan 14 hari. Masing-masing perlakuan dilakukan pengulangan sebanyak dua kali.

\section{Preparasi dan Ekstraksi Daun Pedada}

Daun pedada dipotong kecil-kecil dan dikeringkan di bawah sinar matahari, kemudian dihaluskan hingga ukuran partikel 20 mesh. Tahap selanjutnya adalah ekstraksi. Ekstraksi menggunakan metode maserasi dengan pelarut polar yaitu alkohol $70 \%$. Perbandingan bahan dan pelarut yang digunakan adalah 1:4 selama 3 hari. Kemudian dilakukan penyaringan, filtrat dievaporasi pada suhu $40^{\circ} \mathrm{C}$ menggunakan rotary evaporator hingga diperoleh ekstrak daun pedada.

\section{Aplikasi Ekstrak Daun Pedada pada Ikan}

Ikan yang telah dicuci bersih dengan air mengalir, selanjutnya dicelupkan kedalam masing-masing perlakuan konsentrasi ekstrak daun pedada $(15 \%, 20 \%$, dan $25 \%)$ selama 2 
jam dengan tujuan agar ekstrak daun terserap oleh daging ikan segar (Iswadi et al., 2015). Selanjutnya dilakukan penyimpanan dengan 3 kondisi suhu berbeda yaitu suhu ruang $\left(23^{\circ}\right.$ $\left.27^{\circ} \mathrm{C}\right)$, suhu dingin $\left(10^{\circ} \mathrm{C}\right)$, suhu beku $\left(0^{\circ} \mathrm{C}\right)$ dengan lama penyimpanan 1, 7 dan 14 hari. Parameter yang diuji meliputi nilai $\mathrm{pH}$, kadar air (SNI-01-2354.2.2015), kadar protein (SNI 2354.4-2010), angka lempeng total (ALT)(SNI 01-2332.3.2015) dan E-Coli (SNI 2332.1.2015). Pengolahan data dilakukan menggunakan rancangan acak lengkap (RAK) faktorial dilanjutkan analisis ragam (analysis of variance atau ANOVA).

\section{HASIL DAN PEMBAHASAN}

\section{Analisis pH}

Hasil pengujian nilai $\mathrm{pH}$ pada ikan kembung dengan perbedaan perlakuan suhu dan lama penyimpanan dapat dilihat pada Gambar 1 .

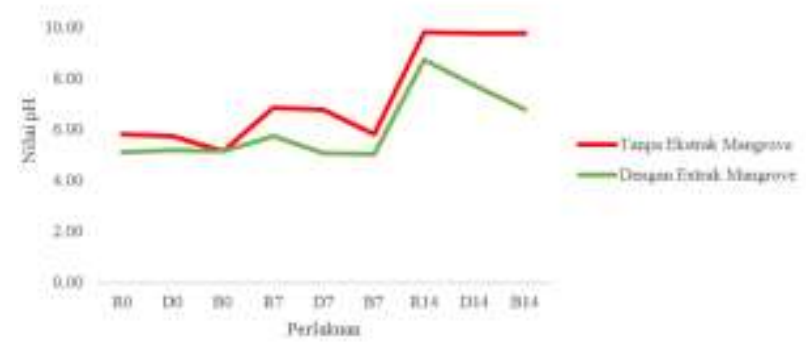

Gambar 1. Grafik Derajat Keasaman $(\mathrm{pH})$ pada Ikan Kembung terhadap Penambahan Ekstrak Daun Pedada, Suhu dan Lama Penyimpanan

Nilai pH ikan dengan penambahan ekstrak daun pedada memiliki nilai $\mathrm{pH}$ yang lebih rendah dibandingkan dengan ikan tanpa penambahan ekstrak. Nilai $\mathrm{pH}$ ikan kembung yang disimpan pada suhu kamar, dingin dan beku pada hari pertama berkisar antara 5,075,84 dengan atau tanpa perlakuan pemberian ekstrak daun pedada. kemudian mengalami kenaikan pada hari ketujuh menjadi kisaran antara 6,77-9,84 dan selanjutnya mengalami penurunan pada penyimpanan hari keempat belas sampai kisaran 5,02-6,79. Hasil analisis ANOVA diperoleh bahwa variasi suhu penyimpanan dan lama penyimpanan pada ikan kembung dengan atau tanpa penambahan ekstrak menunjukkan pengaruh yang signifikan $(\operatorname{sig}<0.05)$ terhadap nilai $\mathrm{pH}$. Pada hari ketujuh terjadi kenaikan $\mathrm{pH}$, hal ini karena terjadinya proses perombakan protein pada daging ikan oleh enzim dan bakteri sehingga terbentuknya senyawa basa seperti amoniak (Husni et al., 2015). pH ikan dengan kondisi penyimpanan beku cenderung memiliki nilai $\mathrm{pH}$ yang lebih rendah dibandingkan penyimpanan ikan pada suhu kamar dan dingin. Penyimpanan ikan pada suhu rendah menyebabkan aktivitas enzim pada ikan menjadi terhambat sehingga kemunduran mutunya berjalan lebih lambat. Semakin rendah suhu yang digunakan maka aktivitas enzim semakin terhambat (Munandar et al., 2009). Selain itu terjadinya penurunan $\mathrm{pH}$ dapat disebabkan terdisosiasinya suatu asam organik dari senyawa metabolit sekunder yang melepaskan ion $\mathrm{H}+$ yang dapat mengikat gugus amino pada protein. Nilai $\mathrm{pH}$ produk pangan yang semakin rendah dapat meningkatkan lamanya waktu simpan produk karena $\mathrm{pH}$ yang rendah akan menghambat perkembangan bakteri (Tria et al., 2018).

\section{Analisis Kadar Air}

Hasil pengujian kadar air ikan kembung yang disimpan selama 1,7 , dan 14 hari pada suhu ruang, dingin, dan beku dengan atau tanpa penambahan ekstrak daun pedada dapat dilihat pada Gambar 2.

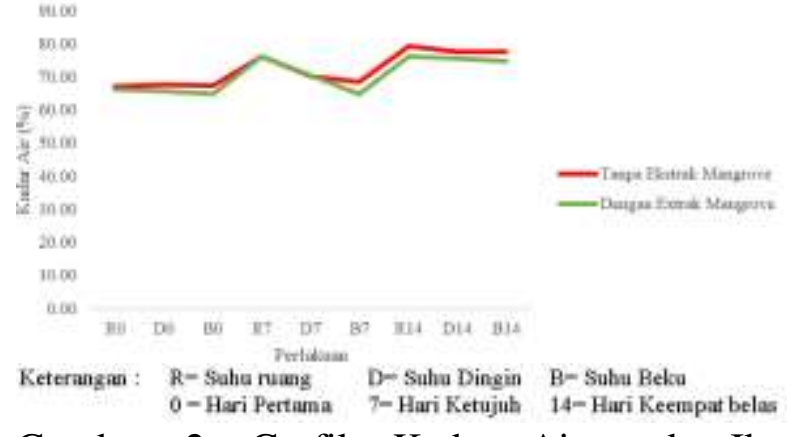

Gambar 2. Grafik Kadar Air pada Ikan Kembung terhadap Penambahan Ekstrak Daun Pedada, Suhu dan Lama Penyimpanan

Data tersebut secara keseluruhan menunjukkan bahwa kadar air ikan kembung tertinggi terdapat pada penyimpanan suhu ruang hari keempat belas tanpa penambahan ekstrak mangrove (R14) yaitu 79,26\%. Kadar air terendah $64,85 \%$ terdapat pada penyimpanan beku hari ke tujuh dengan penambahan ekstrak mangrove (B7). Untuk mengetahui signifikansi variasi suhu penyimpanan dan lama penyimpanan terhadap kadar air maka dilakukan uji analisis ragam ANOVA. Berdasarkan hasil analisis kadar air 
diperoleh bahwa variasi suhu penyimpanan dan lama penyimpanan pada ikan kembung dengan atau tanpa penambahan ekstrak menunjukkan pengaruh yang signifikan $(\operatorname{sig}<0.05)$. Kadar air meningkat disebabkan oleh kondisi penyimpanan suhu ruang yang memicu timbulnya aktivitas bakteri dan enzim yang dapat menguraikan daging dan membebaskan molekul air. Makro molekul seperti protein dan zat gizi lainnya yang terdegradasi oleh mikroba pengurai akan membentuk senyawa yang lebih sederhana dan air (Dasir et al., 2018). Hal ini sejalan dengan penelitian (Rieuwpassa et al., 2017) yang menyatakan bahwa meningkatnya kadar air dikarenakan terjadinya denaturasi protein. Kondisi penyimpanan dan pembekuan yang tepat diperlukan untuk menjaga kualitas produk ikan (Nakazawa \& Okazaki, 2020).

\section{Analisis Kadar Protein}

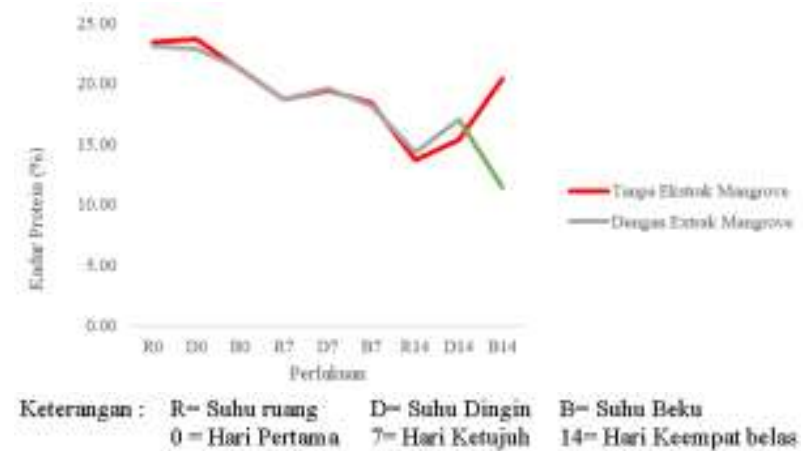

Gambar 3. Grafik Kadar Protein pada Ikan Kembung terhadap Penambahan Ekstrak Daun Pedada, Suhu dan Lama Penyimpanan.

Kadar protein ikan kembung yang disimpan selama 1,7, dan 14 hari pada suhu ruang, dingin, dan beku dengan atau tanpa penambahan ekstrak mangrove dapat dilihat pada Gambar 3. Hasil uji menunjukkan kadar protein tertinggi $23,19 \%$ yaitu pada ikan kembung pada suhu ruang penyimpanan hari pertama dengan atau tanpa penambahan ekstrak daun pedada (R0). Sedangkan kadar protein terendah $11.45 \%$ yang terdapat pada ikan kembung bersuhu beku penyimpanan hari ke 14 dengan penambahan ekstrak daun mangrove. Berdasarkan hasil analisis ANOVA diperoleh bahwa variasi suhu dan lama penyimpanan menunjukkan pengaruh yang signifikan $($ sig<0.05) terhadap kadar protein. Ikan kembung dengan penambahan ekstrak daun pedada mengalami penurunan kadar protein dengan bertambahnya waktu penyimpanan.
Pembekuan menjadi salah satu metode pengawetan ikan segar dan produk perikanan lainnya. Namun proses pembekuan berpengaruh terhadap penurunan kualitas produk selama penyimpanan. Penurunan kandungan nutrisi seperti protein dipengaruhi oleh metode pembekuan, proses thawing, dan fluktuasi suhu (Pourshamsian et al., 2012). Penurunan kualitas produk beku dapat pula disebabkan adanya proses oksidasi, denaturasi protein, sublimasi dan rekristalisasi pada kristal es (Abraha et al., 2018).

\section{Analisis Angka Lempeng Total (ALT)}

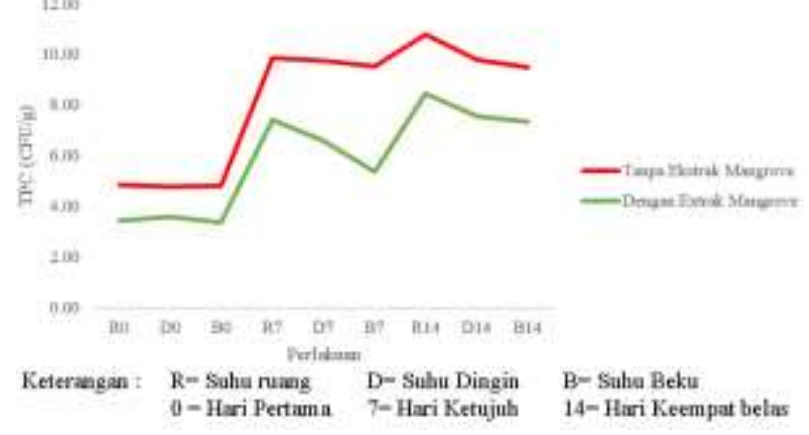

Gambar 4. Grafik Angka Lempeng Total (ALT) pada Ikan Kembung terhadap Penambahan Ekstrak Daun Pedada, Suhu dan Lama Penyimpanan.

Ikan adalah salah satu sumber pangan bergizi tinggi yang mudah rusak. Aktivitas enzim, bakteri dan oksigen menjadi faktor utama yang bertanggung jawab terhadap kerusakan fisiologis dan mikrobiologi produk perikanan. Nilai ALT menjadi penting karena menjadi parameter untuk mikroorganisme. Hasil pengujian ALT ikan kembung yang disimpan selama 1,7 , dan 14 hari pada suhu ruang, dingin, dan beku dengan atau tanpa penambahan ekstrak mangrove dapat dilihat pada Gambar 4.

Hasil nilai ALT tertinggi $10,77 \times 10^{4}$ koloni/gram yaitu ikan kembung pada suhu ruang penyimpanan hari pertama tanpa penambahan ekstrak daun pedada (R0). Sedangkan nilai ALT terendah 3,38 x $10^{4}$ yang terdapat pada ikan kembung suhu beku penyimpanan hari pertama dengan penambahan ekstrak daun mangrove. Hasil analisis ANOVA diperoleh bahwa variasi suhu penyimpanan dan lama penyimpanan pada ikan kembung dengan atau tanpa penambahan ekstrak menunjukkan pengaruh yang signifikan $(\operatorname{sig}<0.05)$ terhadap 
nilai ALT. Secara keseluruhan hasil uji ALT ikan kembung dengan penambahan ekstrak daun pedada menunjukkan total bakteri lebih rendah dibandingkan dengan ikan kembung tanpa penambahan ekstrak daun pedada. Ekstrak daun pedada mengandung senyawa metabolit sekunder seperti terpenoid, alkaloid, senyawa fenolik, dan saponin (Mahmiah \& Andayani, 2016). Tumbuhan menjadi sumber alami dari senyawa metabolit sekunder yang bersifat antibakteri karena mampu menekan pertumbuhan mikroorganisme (Moghrovyan et al., 2019)..

Selain itu kondisi penyimpanan beku menunjukkan nilai ALT lebih rendah dibandingkan kondisi penyimpanan suhu ruang dan dingin. Hal ini sejalan dengan penelitian Rahman et al, ( 2018) yang menyatakan bahwa total bakteri akan berkurang dengan penyimpanan dibawah titik beku diakibatkan terhambatnya aktivitas bakteri pada produk.

\section{Analisis E-Coli}

Hasil analisis e-coli ikan kembung yang disimpan selama 1,7, dan 14 hari pada suhu ruang, dingin, dan beku dengan atau tanpa penambahan ekstrak mangrove dapat dilihat pada Tabel 1. Berdasarkan data tersebut bakteri e-Coli belum terdeteksi pada hari pertama. Bakteri dideteksi positif pada ikan kembung yang disimpan selama 7 dan 14 hari tanpa penambahan ekstrak daun pedada.

Tabel 1. Kandungan E-Coli pada Ikan

\begin{tabular}{|c|c|c|}
\hline Perlakuan & $\begin{array}{c}\text { Tanpa Ekstrak } \\
\text { Mangrove }\end{array}$ & $\begin{array}{c}\text { Dengan } \\
\text { Ekstrak } \\
\text { Mangrove }\end{array}$ \\
\hline R0 & Negatif & Negatif \\
\hline D0 & Negatif & Negatif \\
\hline B0 & Negatif & Negatif \\
\hline R7 & Positif & Positif \\
\hline D7 & Positif & Negatif \\
\hline B7 & Positif & Negatif \\
\hline R14 & Positif & Positif \\
\hline D14 & Positif & Negatif \\
\hline B14 & Positif & Negatif \\
\hline
\end{tabular}

Ikan kembung yang telah ditambahkan ekstrak daun pedada namun disimpan pada suhu ruang juga terdeteksi positif. Hal ini ini menunjukkan bahwa pertumbuhan bakteri dipengaruhi oleh suhu penyimpanan dan aktivitas senyawa bioaktif pada ekstrak yang diaplikasikan pada ikan. Bakteri e-coli dapat tumbuh dan berkembang pada penyimpanan suhu ruang, hal ini didukung oleh penelitian Sumartini, et al (2021). Kandungan alkaloid, fenol dan terpenoid pada ekstrak daun pedada berperan sebagai antibakteri yang menyebabkan hasil uji ikan kembung dengan penambahan ekstrak daun pedada pada penyimpanan suhu dingin dan beku terdeteksi negatif.

Bhimba et al., (2010) dalam penelitiannya juga menyebutkan bahwa ekstrak daun mangrove yang memiliki kandungan senyawa metabolit sekunder mampu menghambat petumbuhan bakteri Eschericia coli (E. coli) dan Staphylococcus aureus.

\section{KESIMPULAN}

Berdasarkan data hasil penelitian menunjukkan bahwa penambahan ekstrak daun pedada, perbedaan suhu penyimpanan, dan lama penyimpanan berpengaruh signifikan $($ sig<0.05) terhadap nilai $\mathrm{pH}$, kadar air, kadar protein dan angka lempeng total (ALT). Selanjutnya hasil uji E-coli diperoleh bahwa perlakuan suhu dingin dan suhu beku pada ikan dengan penambahan ekstrak daun pedada menunjukkan kandungan E-coli negatif.

\section{DAFTAR PUSTAKA}

Abraha, B., Admassu, H., Mahmud, A., Tsighe, N., Shui, X. W., \& Fang, Y. (2018). Effect of processing methods on nutritional and physico-chemical composition of fish: a review. MOJ Food Processing \& Technology, 6(4). https://doi.org/10.15406/mojfpt.2018.06.0 0191

B, V. B., , J Meenupriya , Elsa Lycias Joel, D Edaya Naveena, S. kumar, \& Thangaraj. (2010). Antibacterial activity and characterization of secondary metabolites isolated from mangrove plant Avicennia officinalis. Asian Pacific Journal of Tropical Medicine, 3(7), 544-546. https://doi.org/10.1016/S19957645(10)60131-9

Dasir, D., Suyatno, S., \& Rosmiah, R. (2018). Analisis Karakteristik Fisik dan Kimia 
Surimi Ikan Lele dengan Perlakuan Jenis dan Lama Penyimpanan Dingin Analysis of Physical and Chemical Characteristics of Surimi Lele Fish with Treatment Treatment and Cold Storage Duration. Prosiding Seminar Nasional Lahan Suboptimal, 165-171.

Huang, Y. Z., Liu, Y., Jin, Z., Cheng, Q., Qian, M., Zhu, B. W., \& Dong, X. P. (2021). Sensory evaluation of fresh/frozen mackerel products: A review. Comprehensive Reviews in Food Science and Food Safety, 20(4), 3504-3530. https://doi.org/10.1111/1541-4337.12776

Husni, A., Brata, A. K., \& Budhiyanti, S. A. (2015). Enhancing Shelf Life of Mackerel Fillet using Ethanolic Extract of Seaweed Padina sp. During Storage at Room Temperature. Jurnal Pengolahan Hasil Perikanan Indonesia, 18(1), 1-10. https://doi.org/10.17844/jphpi.2015.18.1. 01

Iswadi, Samingan, \& Sartika, I. (2015). Ekstrak Daun Api-Api (Avicennia marina) Sebagai Antibakteri Dan Pengawet Alami Ikan Tongkol (Euthynus affinis) Segar. Jurnal Biologi Edukasi, 7, 7-12.

Mahmiah, \&, \& Andayani, R. (2016). Phytochemical And Antioxidant Activity Of Mangrove Plant Soneratia sp . 51-54.

Moghrovyan, A., Sahakyan, N., Babayan, A., Chichoyan, N., Petrosyan, M., \& Trchounian, A. (2019). Essential Oil and Ethanol Extract of Oregano (Origanum vulgare L.) from Armenian Flora as a Natural Source of Terpenes, Flavonoids and other Phytochemicals with Antiradical, Antioxidant, Metal Chelating, Tyrosinase Inhibitory and Antibacterial Activity. Current Pharmaceutical Design, 25(16), 1809-1816. https://doi.org/10.2174/13816128256661 90702095612

Munandar, A., Nurjanah, \& Nurilmala, M. (2009). Kemunduran Mutu Ikan Nila (Oreochormis niloticus) pada Penyimpanan Suhu Rendah dengan Perlakuan Cara Kematian dan Penyiangan. Jurnal Teknologi Pengolahan Hasil
Perikanan Indonesia, XI(2), 88-101.

Nakazawa, N., \& Okazaki, E. (2020). Recent research on factors influencing the quality of frozen seafood. Fisheries Science, $86(2)$, 231-244. https://doi.org/10.1007/s12562-02001402-8

Pourshamsian, K., Ghomi, M. R., \& Nikoo, M. (2012). Fatty Acid and Proximate Composition of Farmed Great Sturgeon (Huso huso) Affected by Thawing Methods, Frying Oils and Chill Storage. Advanced Studies in Biology, 4(2), 67-76.

Rahman MA, Hossain MI, S. (2018). Changes in the nutritional composition of Thai pangus (Pangasianodon hypophthalamus) pickle during storage at refrigeration temperature. Journal of the Bangladesh Agricultural University, 16(3),553-559. https://doi.org/10.3329/jbau.v16i3.39455

Rieuwpassa, F. J., Sehangunaung, A. O., \& Dalawir, I. Y. (2017). Analisis Kadar Air dan Total Plate Count Surimi Ikan Tongkol (euthynnus sp.) dan Ikan Layang (Decapterus russelli) Selama Penyimpanan Beku. Jurnal Ilmiah Tindalung, 3(1), 43-47.

Shofiana, I. (2020). Uji aktivitas antibakteri pada Bakteri Salmonella sp. dengan ekstrak kulit batang, daun dan buah Mangrove Sonneratia caseolaris. http://digilib.uinsby.ac.id/id/eprint/43075

Sipayung, B., ruf, W., \& Dewi, E. (2015). Pengaruh Senyawa Bioaktif Buah Mangrove Avicennia Marina Terhadap Tingkat Oksidasi Fillet Ikan Nila Merah O. Niloticus Selama Penyimpanan Dingin. Jurnal Pengolahan Dan Bioteknologi Hasil Perikanan, 4(2), 115-123.

SNI-01-2354.2-. (2015). Pengujian Kadar Air pada Produk Perikanan. 8. http://sispk.bsn.go.id/SNI/Detail SNI/10154

SNI 01-2332.3. (2015). Cara Uji MikrobilogiBagian 3: Penentuan Angka Lempeng Total (ALT) pada Produk Perikanan: SNI 01-2332.3. Badan Standarisasi Nasional, 11. 
SNI 2332.1. (2015). Cara uji mikrobiologi Bagian 1: Penentuan koliform dan Escherichia coli pada produk perikanan. Sni 2332.1:2015, 1-21.

SNI 2354.4-2010. (2010). Cara uji kimia Bagian 4: Penentuan kadar protein dengan metode total nitrogen pada produk perikanan.

Sormin, R. B. D., Leiwakabessy, J., \& Putra, W. H. (2021). The influence of "api-api" (Avicennia marina) leaves extract on the quality of fresh mackerel scad (Decapterus russelli) during storage. IOP Conference Series: Earth and Environmental Science, 805(1). https://doi.org/10.1088/1755$1315 / 805 / 1 / 012023$

Sumartini, Putri Wening Ratrinia, R. A. (2021). The Effect Of Additional Mangrove Leaves ( Avicennia Marina) As An Antibactery In Layang Benggol Fish. Aurelia Journal. 2(2), 171-176.

Tria, G., Nurhamidah, N., \& Amir, H. (2018). Potensi Ekstrak Metabolit Sekunder Eugenia Uniflora L. Sebagai Bahan Pengawet Tahu. Alotrop, 2(1), 39-45. https://doi.org/10.33369/atp.v2i1.4630. 